УДК 94 : 902/904 (477.7) «13/15»

DOI: https://doi.org/10.33782/eminak2021.1(33).511

\title{
ПОСЕЛЕННЯ «ГОРОДОК» I ПЕРСПЕКТИВИ ДОСЛІДЖЕННЯ СЕРЕДНЬОВІЧНОЇ ФОРТЕЦІ «БАЛИКЛЕЙ»
}

\author{
Оксана Господаренко \\ Незалежний дослідник (Миколаїв, Україна) \\ e-mail: kseniagospodarenko@gmail.com \\ ORCID: https://orcid.org/0000-0002-0153-1247
}

У статті подаються результати роботи експедиції Миколаївського державного педагогічного інституту під керівництвом Ю.С. Гребенникова у 1998 р. поблизу с. Городок Варюшинської сільради Веселинівського р-ну Миколаївської обл. Матеріали звіту друкуються вперше.

Як середньовічна пам'ятка, поселення Городок серед археологів відоме також як фортеця Баликлей. Ймовірно, у часи Золотої Орди тут розмішувалася кочова ставка хана, а саме місто було торговим і ремісничим центром у Північно-Західному Причорномор'ї. Це підтверджується знахідками монет золотоординських ханів. $Є$ припущення, що у XV cm. у фортеці знаходився монетний двір (тимчасовий або похідний) і карбували монети хана Менглі-Гірея I (В. Пиворович).

Ключові слова: Баликлей, Золота Орда, археологія, нумізматика, «степові міста»

Здебільшого про існування золотоординських міст ми знаємо з описів мандрівників чи інших письмових джерел XIV-XV ст., або з мап XVII-XVIII ст. Українська золотоординська археологія перебуває у незадовільному стані, тому дослідження проводяться хаотично, а систематизація виявлених і досліджених пам'яток вкрай слабка1. Останнє зауваження стосується і «степових» міст, розташованих на території Миколаївської області. У нашій статті зупинимося на городищі Баликлей.

Городище Баликлей розташовувалося в гирлі р. Чичиклея у місці злиття з Південним Бугом. Ймовірно, городище розміщувалося поблизу села Покровка Веселинівського району Миколаївської області (рис.1). Опис про згадки городища Баликлей у писемних і картографічних джерелах здійснила Ольга Білецька2. Д. Вирський зазначає про першу згадку про Баликлей в ярлику, який бл. 1398 р. Тохтамиш видав Вітовту. За словами історика він прикривав шлях на Очаків. Замок був ключовим у системі оборони Поділля, коли після 1442 р. він став власністю Теодорика Бучацького. 3 переходом Поділля під литовську владу після 1447 р. замок підупадає. У 1546-1547 рр. тут намагалися закріпитися турки. На володіння замком претендували Язловецькі - спадкоємці Бучацьких. А польсь-

\footnotetext{
${ }^{1}$ Вирський Д. Рецензія на: Черкас Б. Західні володіння Улусу Джучи: політична історія, територіально-адміністративний устрій, економіка, міста (XIII-XIV ст.). Київ: Інститут історії України НАН України, 2014. - 386 с. // Український історичний журнал. 2015. Вип. 2 (№ 521). С. 205.

2 Білецька О. «Рибне місце» чи «Долина троянд»: матеріали до вивчення Баликлея // XX Сходознавчі студії А. Кримського. До 145-річчя А. Ю. Кримського та 25-річниці Інституту сходознавства ім. А.Ю. Кримського НАН України. Тези доповідей міжнародної наукової конференції, м. Київ, 17-18 червня 2016 р. Київ, 2016. С. 31-32; Белецкая 0.В. Балыклей в XIV-XVI веках (материалы к изучению исторической географии Подолии и Северного Причерноморья) // Золотоордынская цивилизация. 2017. № 10. С. 398-408.
} 
кий король Генріх Валуа обіцяв відбудувати Баликлей. Д. Вирський також наводить (без посилання на джерела) сумнівну версію про локалізацію замку в с. Баланове Очаківського р-ну Миколаївської обл.)ㄹ. І. Фабрициус подає опис про стан пам'ятки з рукопису В. Гошкевича'.

На сьогодні невідомо, під якою назвою існувало поселення у часи Золотої Орди, але дослідники з упевненістю відносять його існування саме до цих часів 5 . Імовірно, в часи Золотої Орди тут розміщувалася кочова ставка хана, а саме місто було торговим і ремісничим центром у Північно-Західному Причорномор'ї.

Під час експедиції у 1998 р. Миколаївського державного педагогічного інституту під керівництвом Ю.С. Гребенникова, яка проводила дослідження стратифікованого городища та могильника поблизу с. Городок Варюшинської сільради Веселинівського р-ну Миколаївської обл., було встановлено пошкодження більшої частини пам'ятника лісовими насадженнями, зруйнування плантажною оранкою культурного шару в південній частині, за великим валом.

Пам'ятник має три вали: 1-й, найпівденніший, майже не простежується; 2-й ледве помітний, висота не більше 0,3 м; 3-й вал зберігся добре, його висота місцями досягає 2,0 м, добре видний рів шириною до 3,0 м і глибиною не більше 1,0 м6. Про ці вали писав В. Гошкевич: «Поперек всей площади городка насыпаны три земляных вала. Один имеет 132 м длины, 15 м высоты; вдоль него тянется ров шириною 12,75 м, глубиною 6,4 м. На расстоянии 213 м от этого вала идет второй, длиною в 225 м, высотою в 21,3 м; ров при нем длиною 21,3 м, глубиною 6,4 м. Посредине каждого вала - проход, шириною 4,25 м»7. При порівнянні описів стає зрозумілим, що на кінець XX ст. вали вже майже зруйновані.

Під час проведення археологічних робіт на території пам'ятки було розбито 5 шурфів загальною площею 18 кв. м. Шурфи № 1-4 розміщувалися по центральній вісі Північ-Південь, шурф № 5 був розбитий у 15 м на схід від шурфу № 4 (рис. 1).

Шурф № 1. Розмір $2 \times 1$ м, орієнтація широтна. Культурний шар майже відсутній, материковий суглинок почався на глибині 0,45 м. У шарі чорнозему знайдено 2 невиразні фрагменти червоноглиняної кераміки, уламок кістки (можливо, тварина), уламок ліктьової кістки людини, одна мідна монета (рис. 2).

1. Монета середньовічна погана збереженість, ймовірно належить хану Узбеку. Входить до серії монет, описаних нижче (рис. 4.1).

Шурф № 2. Розмір 2×2 м. На глибині 0-0,25 м - гумус, 0,25-0,5 м - культурний шар, далі - материк. Знахідки: 5 невиразних фрагменти червоноглиняної кераміки, 2 фрагменти невиразних кісток тварин, уламок деформованої бронзової пластинки та залізний цвях (рис. 2).

1. Цвях, у розрізі квадрат, довжина 5,5 см, шляпка згнила (рис. 5.11).

Шурфи № 3-5 розміщувалися у «замковій» частині городища, на північ від ве-

\footnotetext{
3 Вирський Д. Річпосполитська історіографія України (XVI - середина XVII ст.) Київ: Інститут історії України НАН України, 2008. Ч. 2 (Додатки), С. 70, прим. 1.

4 Фабрициус И.В. Археологическая карта Причерноморья Украинской ССР. Киев: Изд-во АН УССР, 1951. C. 98.

5 Егоров В.Л. Историческая география Золотой Орды в XIII-XIV вв. Москва: «Наука», 1985. 244 с.; Єльников М.В. Золотоординські часи на українських землях. Київ: Наш час, 2008. 176 с.

6 Гребенников Ю.С., Горбенко К.В. Отчет о работе экспедиции Николаевского педагогического института в 1998 г. // Научный архив Института археологии НАН Украины, 1998/42.

7 Фабрициус И.В. Археологическая карта Причерноморья Украинской ССР. Киев: Изд-во АН УССР, 1951. C. 98.
} 
ликого валу (рис. 1).

Шурф № 3. Розмір 2×2 м. На глибині 0-0,2 м - гумус, 0,2-0,6 м - культурний шар пошкоджений плантажною оранкою, 0,6-0,8 м рештки непошкодженого культурного шару, далі - материк-суглинок із жорствою.

Знахідки: 23 фрагменти кераміки, з них 6 - виразні, 5 різних виробів з бронзи, 8 - із заліза, 1 виріб із срібла, 11 мідних монет, ливарний брак свинцю та бронзового листа. Зі сходу на захід шурф перетинав фундамент стіни з невеликих каменів на щільному глиняному розчині, верхня частина пошкоджена плантажною оранкою, ширина стіни - 0,4-0,5 м. У північно-східному куті виявлена яма (можливо, стовпова) діаметром 0,5 м, глибиною 0,4 м (рис. 3).

1. Фрагмент стінки посудини зі щільної червоно-гарячої глини з дрібним піском. На поверхні зони орнамент - між двома паралельними лініями, такі ж прокреслені хвилясті (рис. 5.1).

2. Фрагмент ручки посудини, глина червона $з$ дрібним піском. Переріз овал з невеликим заглибленням на зовнішній поверхні, 3,5×1,5 см (рис. 5.3).

3. Фрагмент стінки посудини зі щільної червоно-гарячої глини з додаванням слюди. Простежується три ряди добре профільованих канелюр (рис. 5.4).

4. Фрагмент придонної частини посудини зі світлої глини з глазур'ю: на білому фоні синюваті, хвилясті лінії, узор нерозбірливий (рис. 5.2).

5. Округлий виріб з отвором у центрі з тонкої бронзової пластини. Діаметр 3 і 0,7 см (рис. 5.5).

6. Підквадратний виріб з тонкої бронзової пластини, 2,3×0,8 см (рис. 5.8).

7. Конусоподібний виріб з подібним, але меншим отвором у центрі, з тонкої бронзової пластини, $3 \times 1,5$ см (рис. 5.9 ).

8. Виріб з тонкої бронзової проволоки, скручена вісімкоподібно, дві ланки ланцюжка (?), довжина фрагмента - 2,5 см (рис. 5.7).

9. Гудзик-застібка (?). Овальний щиток з більш масивною поперечиною, яка виступає за його краї. Діаметр - 1,5 см (рис. 4.5).

10. Кільце з прямокутного у розрізі залізного прута, діаметр - 4,5 см (рис. 4.8).

11. Ланка ланцюжка з прямокутного у розрізі залізного прута вісімкоподібної форми та частина наступної ланки, довжина - 6,5 см (рис. 4.9).

12. Деформоване кільце з пластинчатого прута 1 мм завтовшки, діаметр кільця - 10 см (рис. 4.10).

13. Залізна пряжка. Кільце з прута прямокутного у розрізі, діаметр - 4 см (рис. 4.11).

14. Лезо невеликого топірця (?). Залізо, фрагмент 5 см (рис. 4.12).

15. Фрагмент леза залізної сокири, довжина фрагменту - 5,5 см (рис. 4.13).

16. Фрагмент клинка меча чи кинджала. Ширина леза - 3,5 см (рис. 4.6).

17. Цвях, стрижень і шляпка прямокутної форми. Довжина 2 см (рис. 5.10).

18. Сережка або підвіска з тонкої срібної пластини з рештками кріплення, форма - трапецієподібна, 2 - 1,2×2,5 см (рис. 4.4).

19. Мідна монета (7 екз.). Аверс - напис арабською в'яззю. Реверс - в центрі розетка у формі колеса, навколо напис, діаметр - 1,7 см (рис. 4.2).

20. Мідна монета (4 екз.) Аверс - напис відмінний від попереднього. Реверс в центрі розетка у формі квітки, діаметр - 2 см (рис. 4.3).

Шурф № 4. Розмір $2 \times 2$ м. Дерновий шар близько 0,3 м, далі материк - вапнякова скеля. Знайдено 5 фрагментів гончарної сіроглиняної кераміки та фрагмен- 
ти від 2 чавунних котлів (рис. 2).

1. Вінцева частина котла у вигляді глибокої миски з прямозрізаним вінцем і внутрішнім бортиком, товщина стінки 0,5 см (рис. 4.7).

2. Вінцева частина котла округлої форми (?). Товщина стінки 0,7 см

Шурфб № 5. Розмір 2×2 м. Дерновий шар - 0,15-0,2 м, до 0,5 м - культурний шар, далі материк - вапнякова жорства. Знайдено 5 фрагментів гончарної кераміки та фрагменти бронзової чаші (рис. 2).

1. Добре профільована гострореберна чаша з бронзового листа, зі злегка стовщеним вінчиком. Розмір фрагмента 7×3 см. Ще два фрагменти сильно зім'яті (рис. 5.6) ${ }^{8}$.

На жаль, планомірних археологічних досліджень на території пам'ятника не проводилось. Але на початку 2000-х рр. т. зв. «чорні археологи» здійснювали там свої пошуки. За інформацією В. Пиворовича, результатом таких пошуків стали велика кількість мідних монет ординських ханів (Узбек, Джанібек, Кільдібек, Абдуллах, Бердибек, Хизра і Тохтамиш), різного типу наслідування, мідні заготовки для чеканки монет, мідний відкований зливок вагою 13,9 г, срібні зливки для виготовлення монетних кружків, скупчення нарубаних вагових шматочків срібла, заготовки монетних кружків і срібні монеті з ім'ям Менглі-Герая I9. Вперше комплекс монет і заготовок був частково опублікований В. Пиворовичем у 2008 р. На підставі цих знахідок дослідник висунув припущення про існування на території фортеці Баликлей монетного двору (тимчасового або похідного) Кримського ханства 10.

Такі знахідки ще раз підтверджують необхідність проведення систематичних археологічних досліджень на території фортеці, оскільки це дасть нові відомості не лише з питань золотоординської нумізматики, а й кримської. Серед істориків, археологів, нумізматів і досі точаться суперечки про місце розташування монетного двора Джучидів у Нижньому Подніпров'ї в XV ст.11

Проведення систематичних досліджень на території пам'ятника дадуть можливість інакше оцінити місце регіону на сухопутних торгових шляхах з Криму до Європи. Останнє є особливо актуальним у зв'язку з припущенням К. Хромова про те, що Баликлей міг бути ключовою точкою на азово-чорноморській ділянці Татарського шляху в XIV ст. За його міркуваннями, «від фортеці ...відкривається досить прямий та практично такий, що не потребує ніяких переправ, шлях до Кам'янця по вододілу між Дністром та Бугом»12. Свого вивчення ще чекає і дос-

\footnotetext{
8 Гребенников Ю.С., Горбенко К.В. Отчет о работе экспедиции Николаевского педагогического института в 1998 г. // Научный архив Института археологии НАН Украины, 1998/42.

9 Пиворович В.Б. К вопросу о чеканке монет Менгли I Гирея на територии крепости Балыклея на p. Южный Буг // Восточная нумизматика в Украине. Часть III. Улус Джучи, Крымское ханство и сопредельные государства в XIII-XVIII вв. Сборник публикаций / Под ред. К.К. Хромова. Киев: Издво «Логос», 2013. С. 76-77.

10 Піворович В.Б. Монети і скарби Півдня України. Херсон, 2008. С. 72-75.

11 Див.: Пачкалов А.В. О локализации монетного двора Орда-Базар (XV в.) // Российская археология. 2005. № 2. С. 87-92; Хромов К. Монетный двор второй четверти XV века «Орда Базар» в нижнеднепровском регионе // Хромов К.К. Восточная нумизматика в Украине. Сборник публикаций. Часть I. Монеты Джучидов XIII-XV веков. Киев, 2004, С. 34-66.

12 Хромов К. Блукаючи шляхами «VIA TATARICA» (проблеми визначення торгових шляхів джучидської доби на теренах сучасної України) // Український нумізматичний щорічник. 2020. Вип. 3. С. 61; Див.: Хромов К.К. Локализация азово-черноморского участка торговой дороги Татарский шлях из Азака во Львов (по нумизматическим данным) // Золотоордынское обозрение. 2020. Т. 8.
} 
лідження часу перебування Баликлея під владою литовських князів і польської влади (мова йде про володіння замком Бучацькими). А також і причини занепаду замку в другій половині XVI ст.

\section{REFERENS}

Beletskaia, O.V. (2017). Balyklei v XIV-XVI vekakh materialy k izucheniiu istoricheskoi geografii Podolii i Severnogo Prichernomoria [Balykley in the $14^{\text {th }}-16^{\text {th }}$ centuries (materials of the historical geography of Podolia and the Northern Black Sea Region)]. Zolotoordynskaia tsivilizatsiia, 10, 398-408 [in Russian].

Biletska, 0. (2016). «Rybne mistse» chy «Dolyna troiand»: materialy do vyvchennia Balykleia [«Fish Place» or «Valley of Roses»: materials to study Balykleya]. Abstracts of Papers: XX Skhodoznavchi studii A. Krymskoho, Kyiv, pp. 31-32 [in Ukrainian].

Egorov, V.L. (1985). Istoricheskaia geografiia Zolotoi Ordy v XIII-XIV vv. [Historical geography of the Golden Horde in the XIII-XIV centuries]. Moskva: Nauka [in Russian].

Fabritsius, I.V. (1951). Arkheologicheskaia karta Prichernomoria Ukrainskoi SSR [Archaeological map of the Black Sea coast of the Ukrainian SSR]. Kiev: Izd-vo AN USSR [in Russian].

Grebennikov, Yu.S. \& Gorbenko, K.V. (1998). Otchet o rabote ekspeditsii Nikolaevskogo pedagogicheskogo instituta $v 1998 \mathrm{~g}$. [Report on work of expedition of the Nikolaev pedagogical institute in 1998]. The Scientific Archive of Institute Archaeology of NAS of Ukraine, 42 [in Russian].

Khromov, K. (2020). Blukaiuchy shliakhamy «VIA TATARICA» (problemy vyznachennia torhovykh shliakhiv dzhuchydskoi doby na terenakh suchasnoi Ukrainy) [Wandering along the roads «VIA TATARICA» (Problems of determining the trade routes of the Juchid era in the territory of modern Ukraine)]. Ukrainskyi numizmatychnyi shchorichnyk, 3, 53-66 [in Ukrainian].

Khromov, K. (2020). Lokalizatsiia azovo-chernomorskogo uchastka torgovoi dorogi Tatarskii shliakh iz Azaka vo Lvov po numizmaticheskim dannym [The location of the Tatar shlyakh trade road from Azaq to Lviv along the Northern Coast of Azov Sea and Black Sea (according to numismatic data)]. Zolotoordynskoe obozrenie, 8 (2), 274-283 [in Russian].

Khromov, K. (2004). Monetnyi dvor vtoroi chetverti XV veka Orda Bazar v nizhnedneprovskom regione [Mint of the second quarter of the $15^{\text {th }}$ century «Horde Bazar» in the Lower Dnieper region] In Khromov, K.K. Vostochnaia numizmatika v Ukraine. Sbornik publikatsii. Vol. I: Monety Dzhuchidov XIII-XV vekov. Kiev [in Ukrainian].

Pachkalov, A.V. (2005). O lokalizatsii monetnogo dvora Orda-Bazar (XV v.) [About localization of the Orda-Bazar mint (15th century)]. Rossiiskaia arkheologiia, 2, 87-92 [in Russian].

Pivorovich, V.B. (2013). K voprosu o chekanke monet Mengli I Gireia na teritorii kreposti Balykleia na r. Yuzhnyi Bug [On the issue of minting coins of Mengli I Girey on the territory of the Balikleya fortress on the Southern Bug river] In Khromov, K.K. Vostochnaia numizmatika v Ukraine. Vol. III: Ulus Dzhuchi, Krymskoe khanstvo i sopredelnye gosudarstva v XIII-XVIII vv. Kyiv: Logos [in Russian].

Pivorovych, V.B. (2008). Monety i skarby Pivdnia Ukrainy [Coins and Noards of the Southern Ukraine]. Kherson [in Ukrainian].

Vyrskyi, D. (2015). Retsenziia na: Cherkas B. Zakhidni volodinnia Ulusu Dzhuchy: politychna istoriia, terytorialno-administratyvnyi ustrii, ekonomika, mista (XIII-XIV st.). K.: Instytut istorii Ukrainy NAN Ukrainy, 2014 [Review of: Cherkasy B. Western possessions of Ulus Juchi: political history, territorial-administrative system, economy, cities (XIII-XIV centuries). K.: Institute of History of Ukraine, National Academy of Sciences of Ukraine, 2014]. Ukrainskyi istorychnyi zhurnal, 2, 197-205 [in Ukrainian].

Yelnykov, M.V. (2008). Zolotoordynski chasy na ukrainskykh zemliakh [Golden Horde times in the Ukrainian lands]. Kyiv: Nash chas [in Ukrainian]. 


\author{
Oksana Gospodarenko \\ (Independent researcher, Mykolaiv, Ukraine) \\ e-mail: kseniagospodarenko@gmail.com \\ ORCID: https://orcid.org/0000-0002-0153-1247
}

\title{
Settlement 'Horodok' and Prospects for Medieval Fortress of 'Balyklei’ Studying
}

In 1998, MDPI (Mykolaiv State Pedagogical Institute) expedition headed by Yu.S. Hrebennikov conducted a study of a stratified settlement and burial ground near the village of Horodok of Variushyne Village Council of Veselynove Raion of Mykolaiv Oblast. It was found out that the largest part of the site was damaged during the forest plantings. Deep draining plowing completely destroyed the cultural layer in the southern part, behind the biggest rampart. The site has three ramparts: the first, the southernmost, is almost unnoticeable; the $2^{\text {nd }}$ is barely noticeable, with the height of not more than $0.3 \mathrm{~m}$; the $3^{\text {rd }}$ rampart is well preserved, and its height reaches $2.0 \mathrm{~m}$ in some places. There is also a clearly noticeable moat up to $3.0 \mathrm{~m}$ wide and no more than $1.0 \mathrm{~m}$ deep.

To carry out the planned research, 5 prospect holes with a total area of 18 square meters were sunk. The holes № 1-4 were located along the central North-South axis, the hole № 5 was sunk 15 m east from the hole № 4. The holes № 3-5 were located in the 'castle' part of the ancient settlement, to the north of the biggest rampart.

As a medieval site, the settlement of Horodok is also known among archaeologists as the fortress of Balyklei. Supposedly, during the time of the Golden Horde, the nomadic headquarters of the khan were located here, and the city itself was a trade and craft center of the NorthWestern Black Sea region. This is confirmed by the finds of coins of such khans as Uzbek, Janibek, Kildibek, Abdullah, Berdi Beg, Khidr, and Tokhtamysh. There is also an assumption that in the $15^{\text {th }}$ century in the fortress there was a mint (temporary or field) and the coins of Khan Mengli I Giray (V. Pyvorovych) were minted there.

Most information about the Golden Horde cities we have got from the descriptions of travelers or other written sources of the $14^{\text {th }}-15^{\text {th }}$ centuries or from maps of the $17^{\text {th }}-18^{\text {th }}$ centuries. Ukrainian Golden Horde archeology is in an unsatisfactory condition, so researches are being conducted chaotically, and the systematization of discovered and studied sites is extremely poor. The last remark is also true concerning the 'steppe cities' located on the territory of Mykolaiv Oblast.

Carrying out systematic research on the territory of Balyklei will give an opportunity to reconsider the region's place on the land trade routes from the Crimea to Europe, to study the Golden Horde city organization, to broaden the knowledge on the Golden Horde, and the Crimean numismatics.

Keywords: Balyklei, Golden Horde, archeology, numismatics, 'steppe cities' 


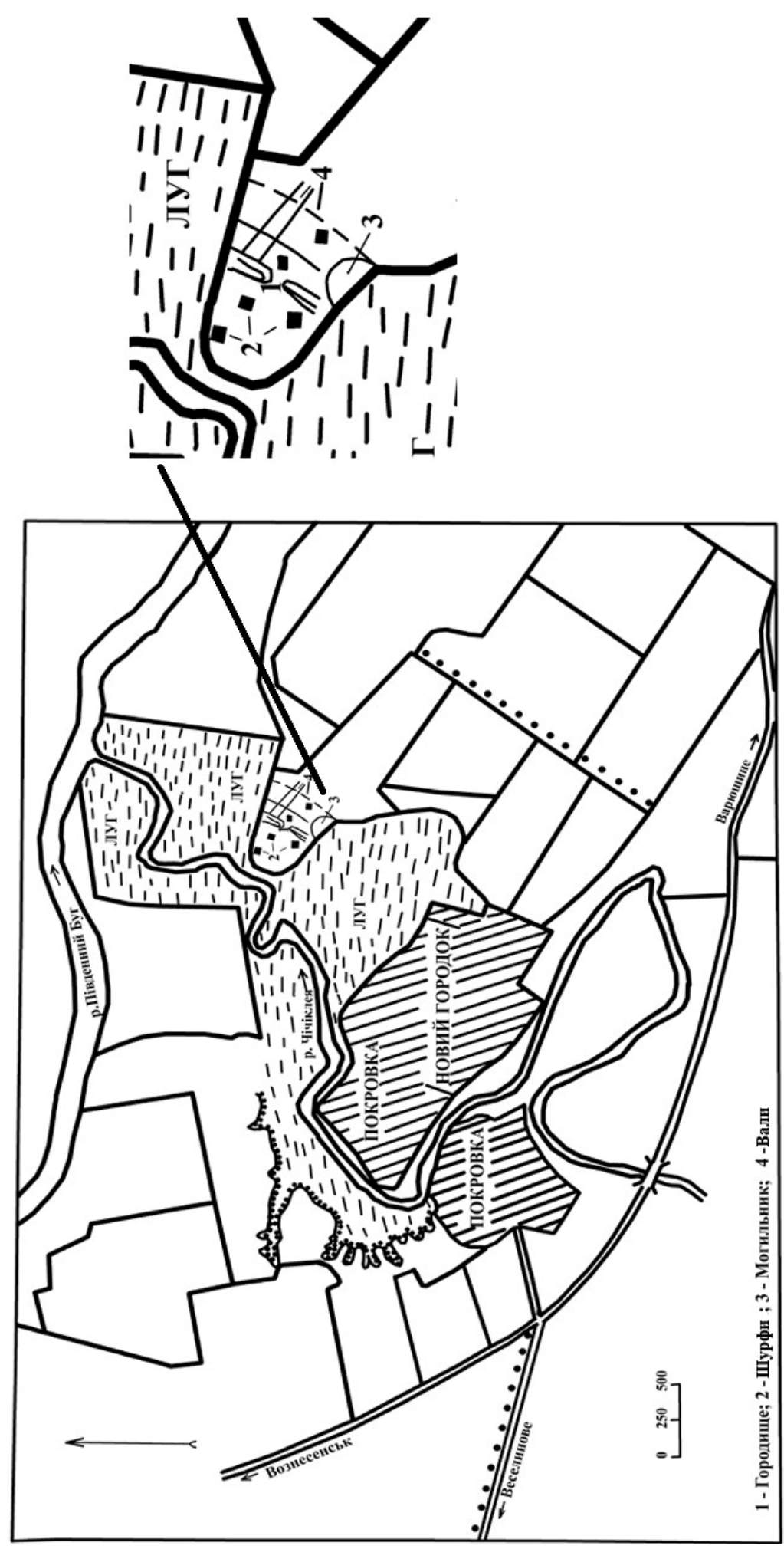

 
Шурф №2

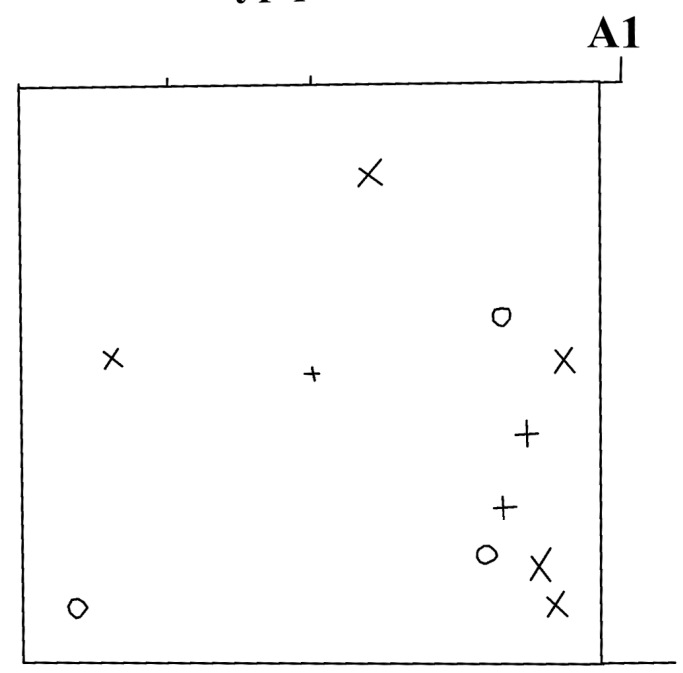

\begin{tabular}{llll}
0 & 25 & 50 & 75 \\
\hline
\end{tabular}
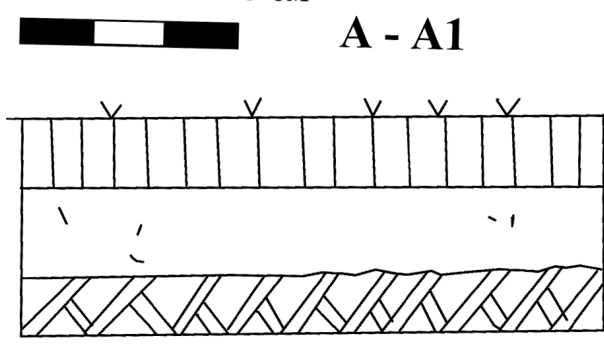

Шурф №4

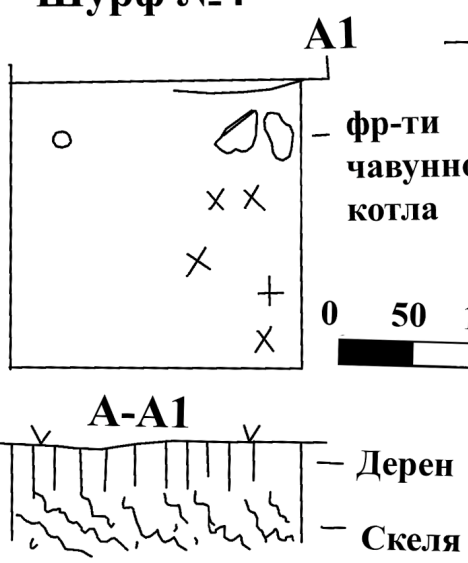

Шурф №1
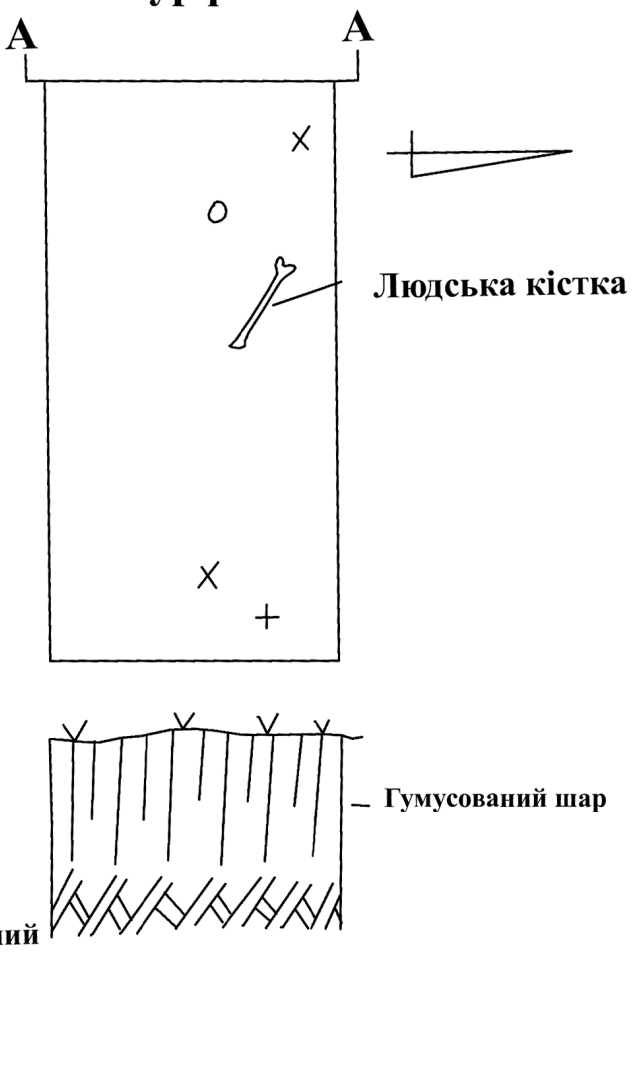

культурний

шар

- Материк

\section{Шурф №5}

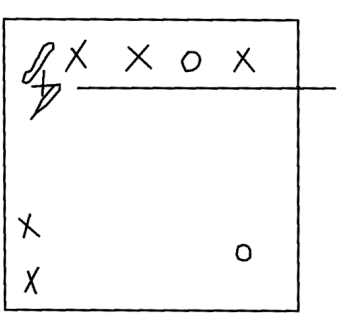

Фр-ти

бронзової

чаші

Рис. 2. Плани шурфів № 1-2, 3-4 (зі звіту Ю.С. Гребенникова). 
Варюшино - гор. «Городок - I»

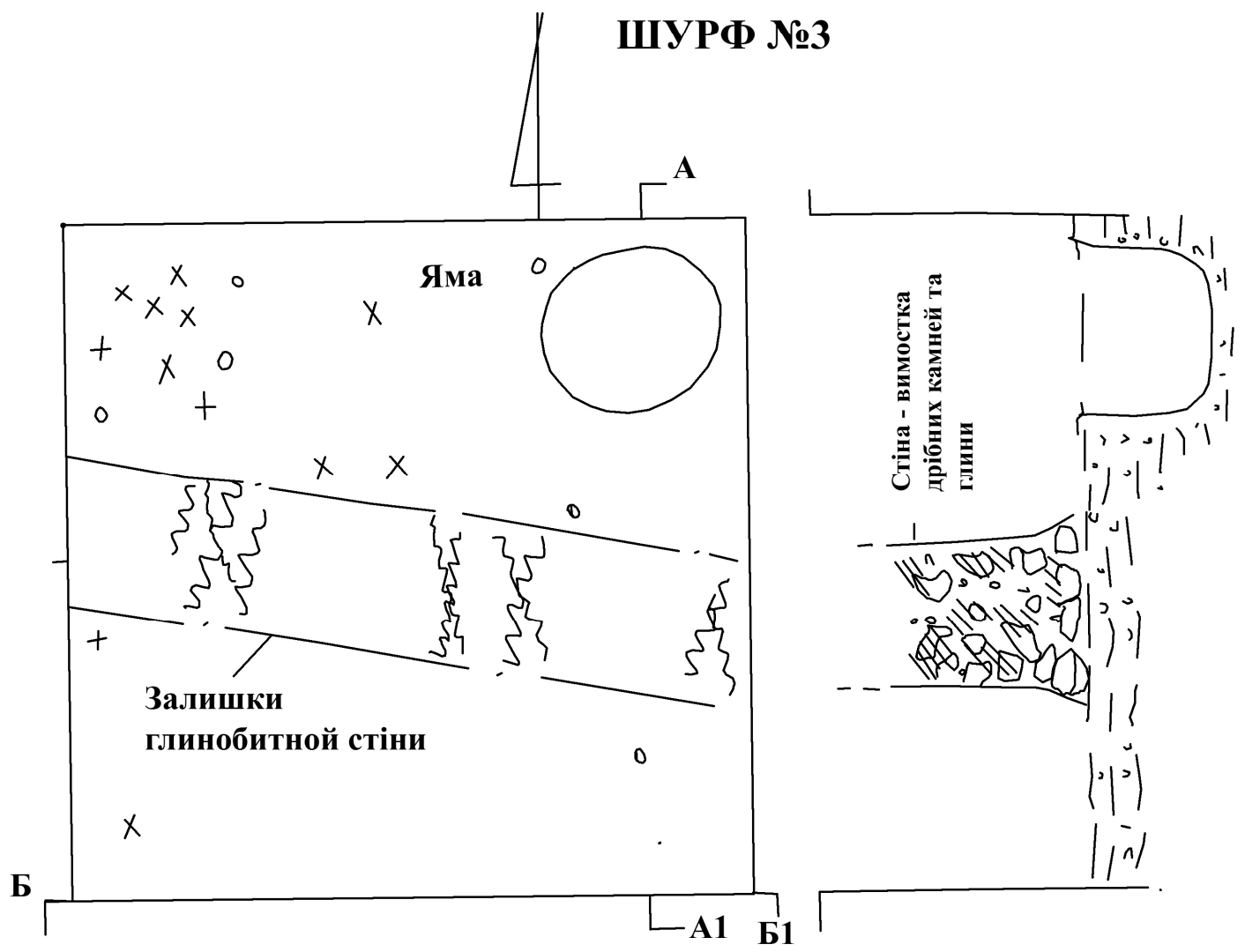

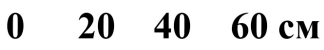

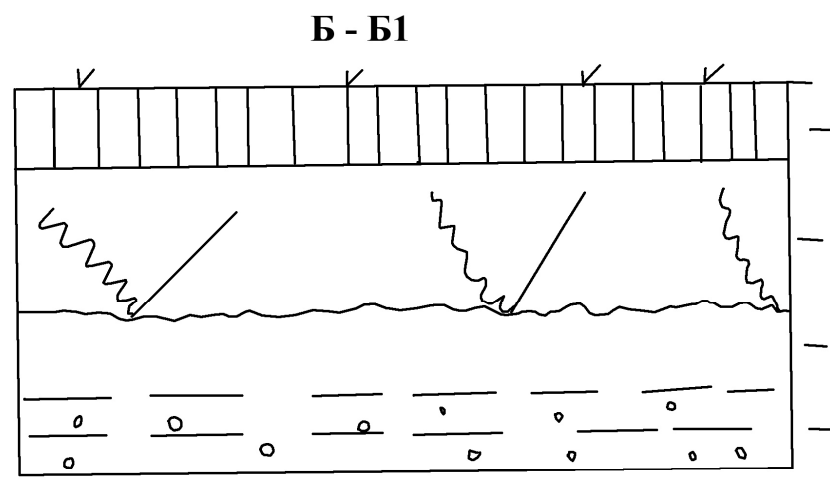

- Сучасний гумусний шар

Культурний шар потривожений оранкою

- Культурний шар

Материк, суглинок с

$$
\begin{aligned}
& X-\text { керамика } \\
& +- \text { інші знахідки }
\end{aligned}
$$

Рис. 3. План шурфа № 3 (зі звіту Ю.С. Гребенникова). 

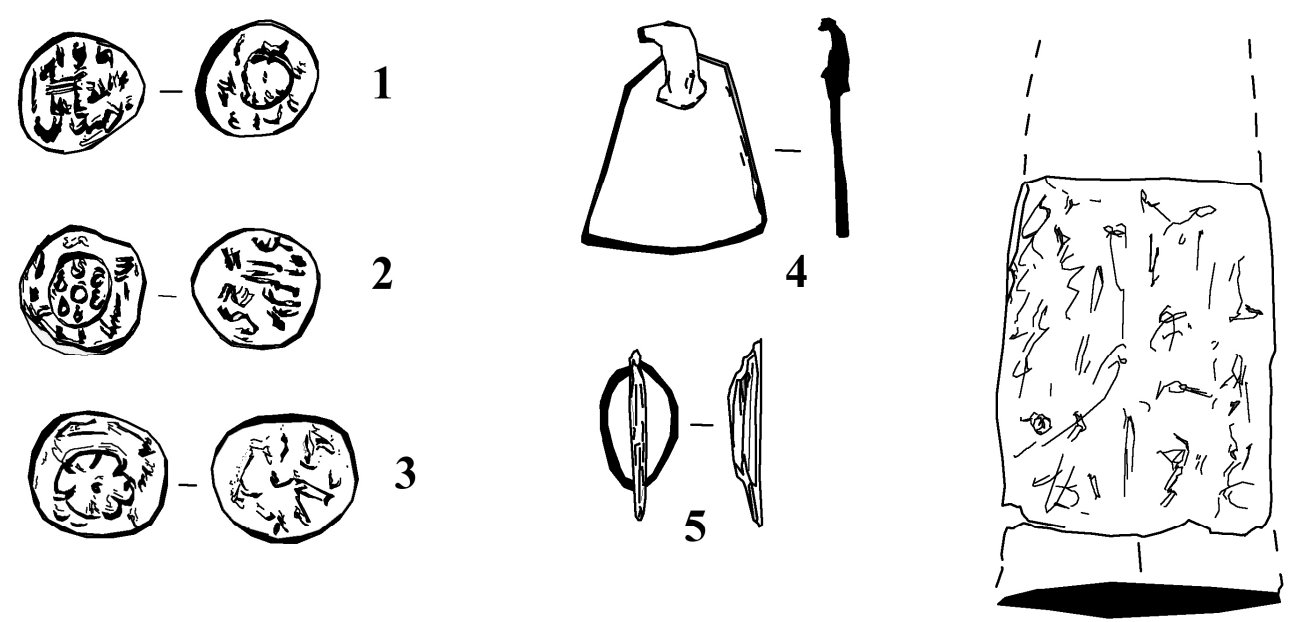

6
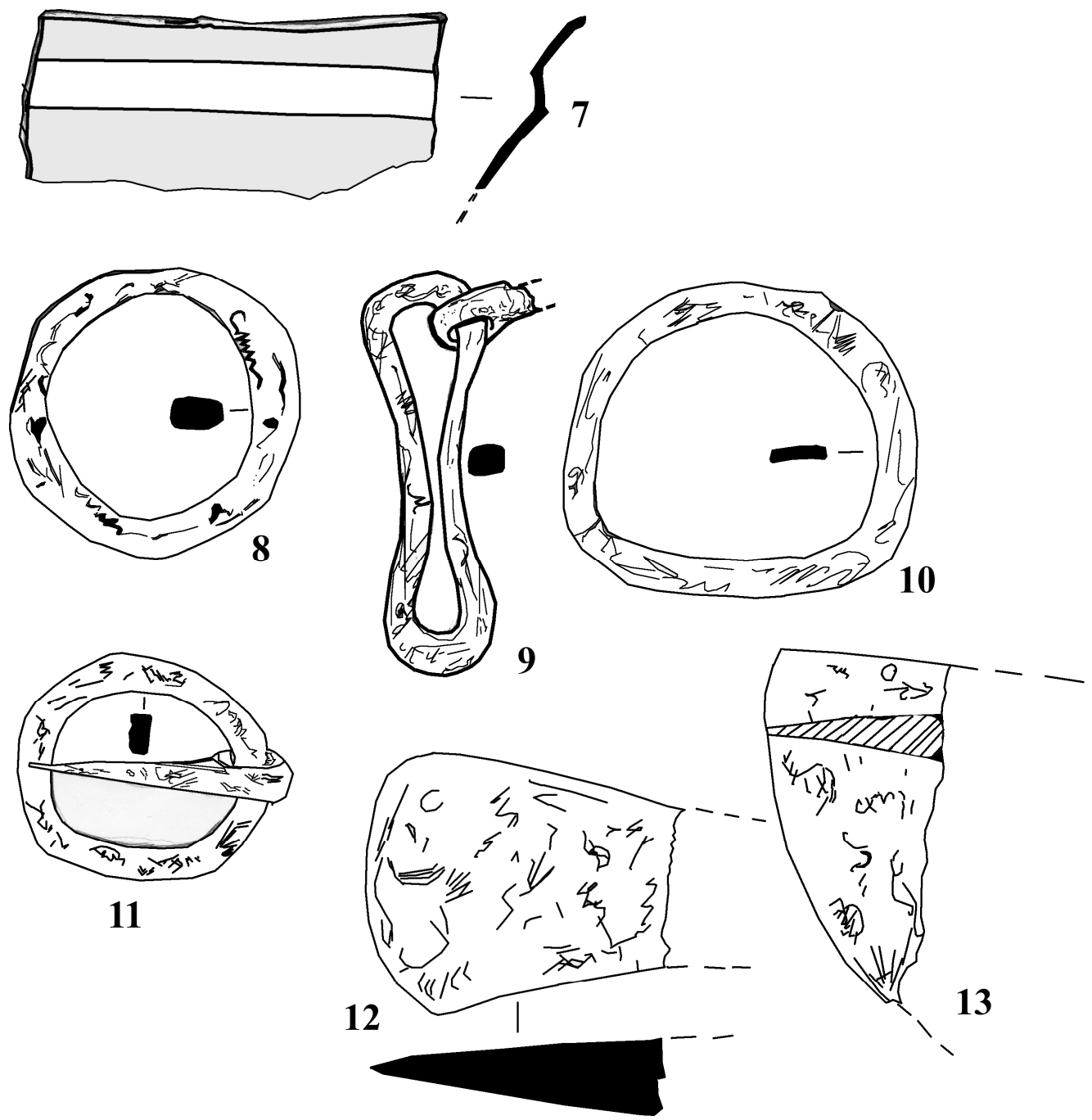

Рис. 4. Знахідки з розкопок 1998 р. (зі звіту Ю.С. Гребенникова). 

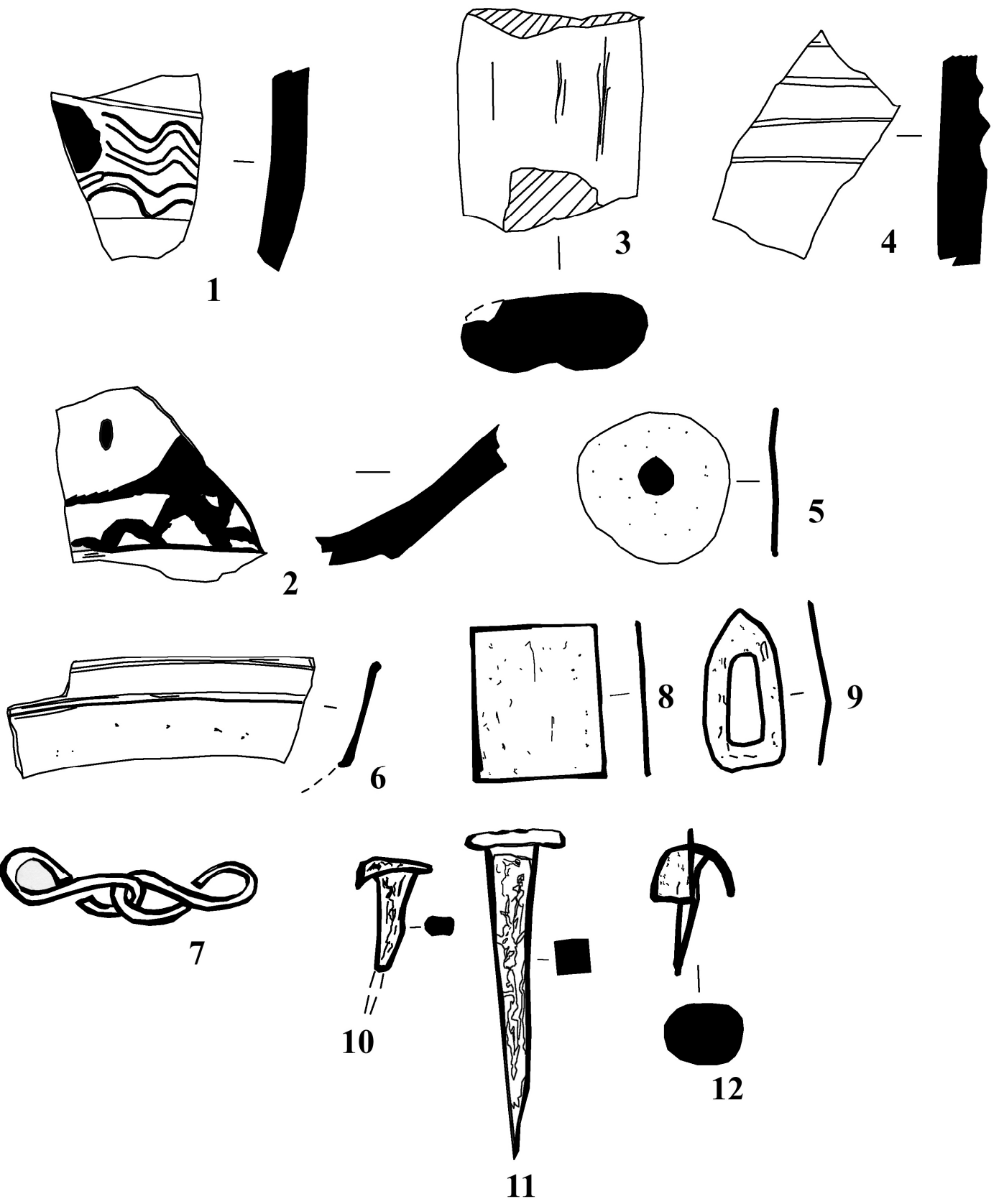

Рис. 5. Знахідки з розкопок 1998 р. (зі звіту Ю.С. Гребенникова). 